Bangladesh J. Bot. 49(3): 567-577, 2020 (September)

\title{
EFFECTS OF PLANT GROWTH REGULATORS ON QUALITY FLOWER AND SEED PRODUCTION OF MARIGOLD (TAGETES ERECTA L.)
}

\author{
Parveen Kumar, Arvinder Singh, Nomita Laishram*, RK Pandey, \\ Sheetal Dogra, M Iqbal Jeelani and BK Sinha \\ Sher-e-Kashmir University of Agricultural Sciences \& Technology of Jammu, \\ Jammu and Kashmir-180009, India
}

Keywords: Seed production, Marigold, Growth regulators

\begin{abstract}
Effects of different growth regulators and their application time on production of quality flower and seed production of marigold (Tagetes erecta L.) were investigated. Experimental factors include nine foliar applications of growth regulators viz., Control (no application), two doses each of $\mathrm{GA}_{3}$, salicylic acid, benzyl adenine, cycocel, and two application times viz., (i) application at 25 DAT, (ii) application at 50 DAT. Results suggest that foliar spray of $250 \mathrm{ppm}$ gibberellic acid enhanced growth, and improved seed yield and quality parameters of marigold. Among the times of application tested, it was observed that application at 25 days after transplanting (DAT) gave superior values for all the flower and seed parameters under study.

\section{Introduction}

Marigold (Tagetes erecta L.) is one of the leading loose flower crops grown in Jammu city of Jammu and Kashmir state of India. Jammu being acclaimed as the city of temples has great demand of marigold flowers round the year. Marigold flowers made its place in all occasions, may be it is a festival, a celebration or a ritual function, more oftenly it is used in religious offereings on a large scale in temples. The production of flowers in Jammu alone cannot meet the everincreasing demand. Hence, flowers need to be procured from neighbouring states also. Also, the demand of the ever increasing quality seeds of marigold needs to be fulfilled. Ease of cultivation and increasing monetary benefits has urged many farmers of Jammu for its cultivation on a commercial scale. To rule out this limitation and to fulfill the demand, it is necessary to increase its production through improved production technologies. Adoption of improved cultural practices appreciably leads to increased productivity which will further boost the production of marigold crop. Keeping in view the importance of the crop and the present demand of marigold flowers in Jammu region, the investigation was undertaken to find out the effects of growth regulators and time of application to improve the quality of flower and seed production of marigold.
\end{abstract}

\section{Materials and Methods}

The present investigation was carried out at the Experimental Farm of the Division of Vegetable Science and Floriculture, Faculty of Agriculture, SKUAST-Jammu during the year 2016-17. The farm is situated at $32^{\circ} 40^{\prime} \mathrm{N}$ latitude and $74^{\circ} 58^{\prime} \mathrm{E}$ longitude and has an elevation of $332 \mathrm{~m}$ above mean sea level. The experiment was laid out in a Factorial Randomized Block Design with 18 treatment combinations. There were nine growth regulator treatments viz., (1)

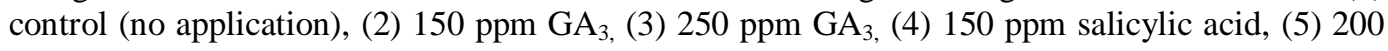
ppm salicylic acid, (6) 75 ppm benzyl adenine, (7) 100 ppm benzyl adenine, (8) 1000 ppm cycocel and (9) $1500 \mathrm{ppm}$ cycocel and two application times $\left(\mathrm{T}_{1}-25\right.$ DAT and $\left.\mathrm{T}_{2}-50 \mathrm{DAT}\right)$ with 3 replicates. The growth regulators were given as foliar sprays as per the experimental treatments.

*Author for correspondence: <nomitalaishram@gmail.com>. 
African marigold cultivar "Pusa Narangi Gainda" was used for the experimental studies. Healthy seedlings with 3 - 4 leaves were transplanted on last week of October in the experimental plots at a spacing of $40 \mathrm{~cm} \times 40 \mathrm{~cm}$ thereby accommodating 16 seedlings per bed size of $1.60 \mathrm{~m}^{2}$.

Farm yard manure @ $20 \mathrm{t} / \mathrm{ha}, 120 \mathrm{~kg} \mathrm{~N}, 100 \mathrm{~kg} \mathrm{P}_{2} \mathrm{O}_{5}$ and $100 \mathrm{~kg} \mathrm{~K} 2 \mathrm{O}$ per hectare was applied. FYM was mixed thoroughly at the time of transplanting along with half dose of $\mathrm{N}$ and full doses of $\mathrm{P}_{2} \mathrm{O}_{5}$ and $\mathrm{K}_{2} \mathrm{O}$. Remaining half dose of $\mathrm{N}$ was applied after 45 days of transplanting. Irrigations were given as and when required during the crop growth. All other cultural practices, e.g. weeding and hoeing were kept similar for all treatments during the entire cropping period of the crop. Data on various growth and flowering parameters were recorded and statistically analyzed by applying the technique of analysis of variance using Factorial Randomized Block Design (Gomez and Gomez 1985). The level of significance was kept at 5\% ( $<$ <.05). Data were analyzed using R. Software program, version 3.4.1.

\section{Results and Discussion}

Maximum plant height and plant spread of 65.44 and $57.70 \mathrm{~cm}$ were recorded with $250 \mathrm{ppm}$ $\mathrm{GA}_{3}$ whereas, minimum plant height $(49.75 \mathrm{~cm})$ and plant spread $(45.90 \mathrm{~cm})$ were recorded with the application of CCC @ 1500. GA 3 induce active cell division and cell elongation, increase the auxin level of tissues and enhance the conversion of tryptophan to IAA, which in turn cause active cell division and cell elongation (Abel and Theologis 1996). Growth might also be increased due to osmotic uptake of water and nutrients under the influence of $\mathrm{GA}_{3}$ which maintain swelling force against the softening of cell wall and thereby increasing the plant height (Lockhart 1960). The reduction in plant height and plant spread with the application of cycocel may be due to inhibitory role of cycocel on cell division and cell elongation of apical meristematic cells and also on gibberellins synthesis. Similar findings were earlier reported by Tripathi et al. (2013) and Kumar et al. (2014).

Regarding the times of application, highest values of the above said parameters at 25 days of transplanting were recorded. Increased efficiency of growth regulators with application at 25 days after transplanting might be due to application of growth regulator at the juvenile stage which causes rapid growth in the initial period. As a result the advantage was carried forward to the end of the experiment as compared to application at 50 days after transplanting when the plant has almost attained its maturity. These results are in close conformity with the findings of Meher et al. (1999).

Number of laterals (12.30) however, was recorded maximum with foliar application of 100 ppm benzyl adenine. The reason behind the increased number of laterals with benzyl adenine might be that cytokinins are known to increase the nutrient sink activity (Salisbury and Ross 1999). They are known to promote lateral bud development thereby by increasing the number of laterals.

Maximum shoot, $(282.33 \mathrm{~g})$ and root fresh weight (47.63 g) resulting in maximum root/shoot ratio on fresh weight basis (0.239) was recorded with application of $250 \mathrm{ppm} \mathrm{GA}_{3}$. However, none of the plant growth regulator treatments and their application time could significantly affect the shoot and root dry weight. Increase in shoot and root fresh weight with $\mathrm{GA}_{3}$ application might be due to higher vegetative- and root growth under the influence of $\mathrm{GA}_{3}$. Change in root : shoot ratio during a plant's life cycle is part of an intrinsic ontogeny, but growth rates of roots and shoots continually adjust to resource availability with photo assimilate. The $\mathrm{GA}_{3}$ mediated enhancement in growth, biomass production and carbohydrate content in crop plants may lead to increased root : shoot ratio as observed by Demura and Ye (2010). These results are in close conformity with the findings of Sujatha et al. (2002) in gerbera. 


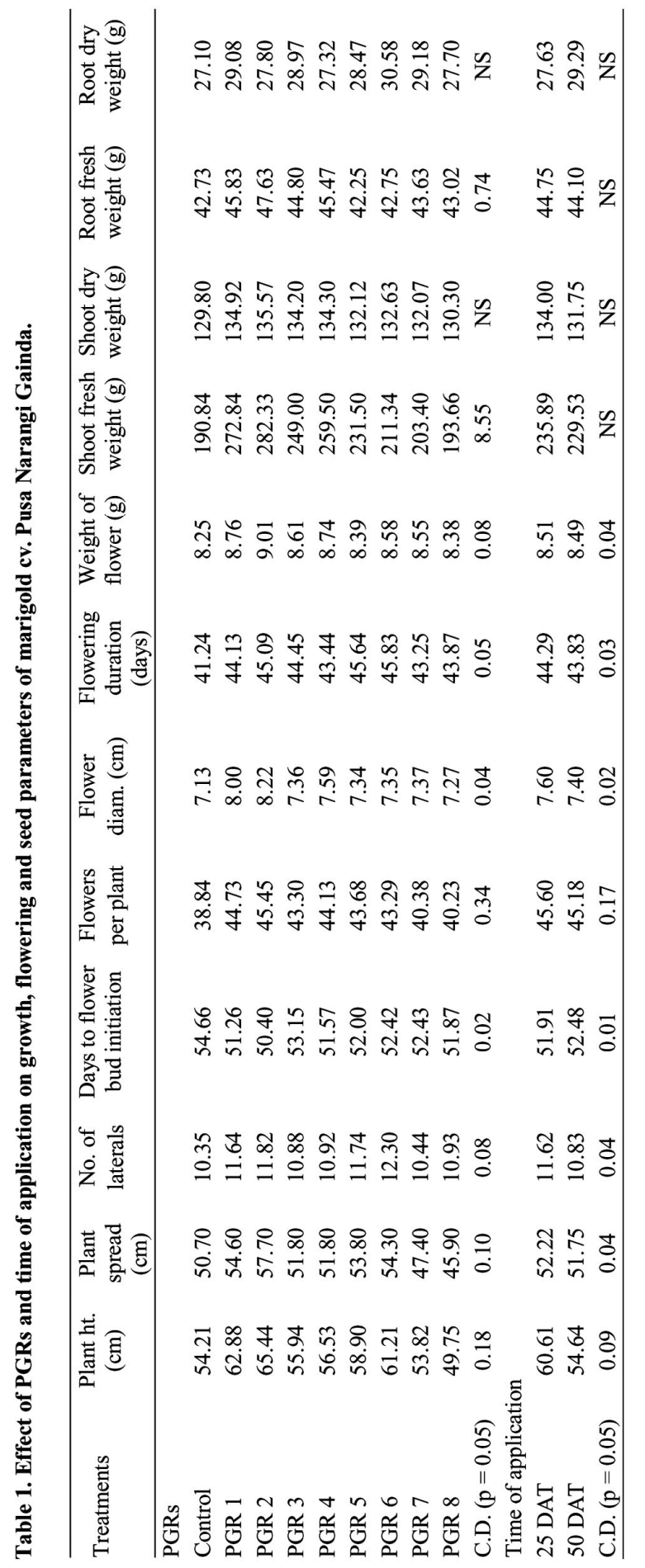




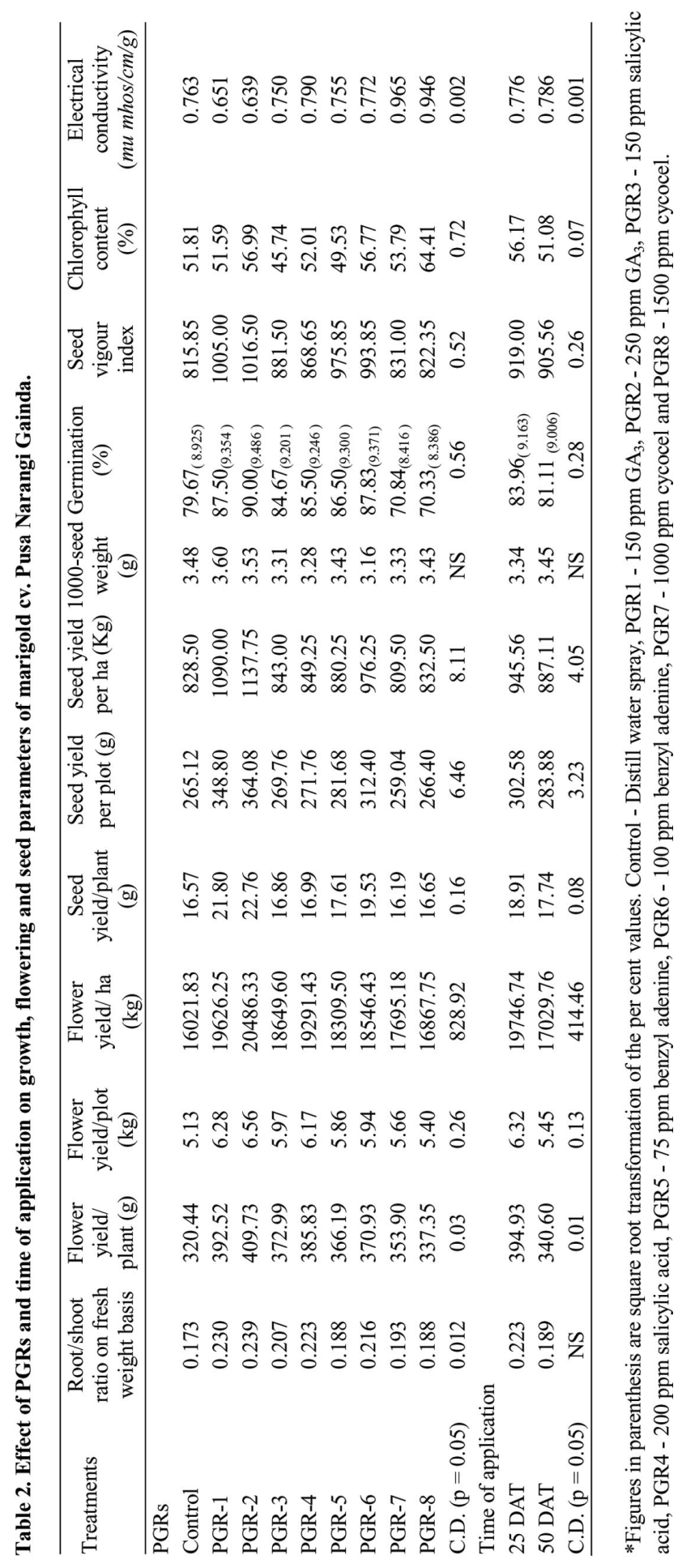


Irrespective of growth regulators used and their doses, all the treatments proved more superior over control in terms of flower quality and yield parameters. However, application of $250 \mathrm{ppm}$ $\mathrm{GA}_{3}$ resulted in earlier flower bud initiation (50.40 days), a greater number of flowers per plant (45.45), more flower diameter $(8.22 \mathrm{~cm})$, maximum flower weight $(9.01 \mathrm{~g})$ and highest flower yield per plant $(409.73 \mathrm{~g})$ as compared to other treatments and control. Maximum flowering duration (45.83 days) on the other hand was observed with the application of $100 \mathrm{ppm}$ Benzyl adenine which was significantly superior from other treatments. Among the time of application, application at 25 days after transplanting recorded superior values for all the flowering parameters.

Early budding and flowering with $\mathrm{GA}_{3}$ application might be due to increase in the endogenous gibberellins level in the plants, as gibberellins are well known for inducing early budding and flowering in several crop plants. The major changes in flowering and yield parameters can be explained by the fact that $\mathrm{GA}_{3}$ was quite effective in reducing the juvenile period of plants because of its higher capacity of cell division and cell elongation which cause early maturity in plants. Moreover, the increase in flowering parameters might also be due to increase in overall vegetative growth of the plants facilitating more photosynthetic area and metabolic activities resulting in more transport and utilization of the photosynthetic product which ultimately resulted in higher flower quality and yield. These results are also in agreement with the reports of Sainath et.al. (2014) in annual chrysanthemum, Kumar et al. (2015) in China aster and Syiemlieh et al. (2016) in petunia.

Dalal et al. (2009) stated that the increment in flower diameter with $\mathrm{GA}_{3}$ application might be due to enhanced cell division and cell enlargement, promotion of protein synthesis coupled with higher dry matter accumulation. Similar observations were also reported by Tyagi and Kumar (2006). Sunitha et al. (2007) were of the opinion that the enhancement in number of flowers per plant in marigold by application of giberrellic acid might be due to the production of large number of laterals at early stage of growth which had sufficient time to accumulate carbohydrate for proper flower bud differentiation due to enhanced reproductive efficiency and photosynthesis in restructured plant type which ultimately increased the yield per plot and per hectare. Verma and Arha (2004) and Devadanam et al. (2007) also observed maximum flower yield per hectare with $\mathrm{GA}_{3}$ treatment.

The increase in yield and yield parameters with $\mathrm{GA}_{3}$ spray may also be correlated to better crop growth, and more number of flowers per plant and maximum fresh weight of individual flower thus ultimately increasing the flower yield/plant. Further, it can also be ascribed due to better translocation of more metabolities from source to sink. Similar results were also reported by Doddagoudar et al. (2004) in China aster, Singh et al. (2009) in chrysanthemum and Kumar et al. (2009) in tuberose.

Increased loose flower yield in plants treated with $\mathrm{GA}_{3} @ 250 \mathrm{ppm}$ might be probably due to the production of flowers with greater diameter and increased fresh weight. Greater diameter can be induced through increased number of florets as a result of better nutrition during reproductive phase. All these factors ultimately contributed to the better partitioning of photosynthates to reproductive sinks under the control of $\mathrm{GA}_{3}$ (Morris 1996). $\mathrm{GA}_{3}$ mediated yield increment in African marigold and other ornamentals were also reported by Tyagi and Kumar (2006).

Increase in flowering duration with the application of benzyl adenine might be due to alleviation of the detrimental effects of senescence by modulating the activity of enzymatic antioxidants, and improving antioxidant system, which helped in sustaining plant growth and flowering. Mutui et al. (2004) also investigated the response of benzyl adenine on the vase life of Alstroemeria cut flowers and observed that treatment of Alstroemeria cut flowers with 25 or 50 
$\mathrm{mg} / \mathrm{l}$ benzyl adenine consistently increased the number of days to full opening of primary florets and delayed the start of flower senescence.
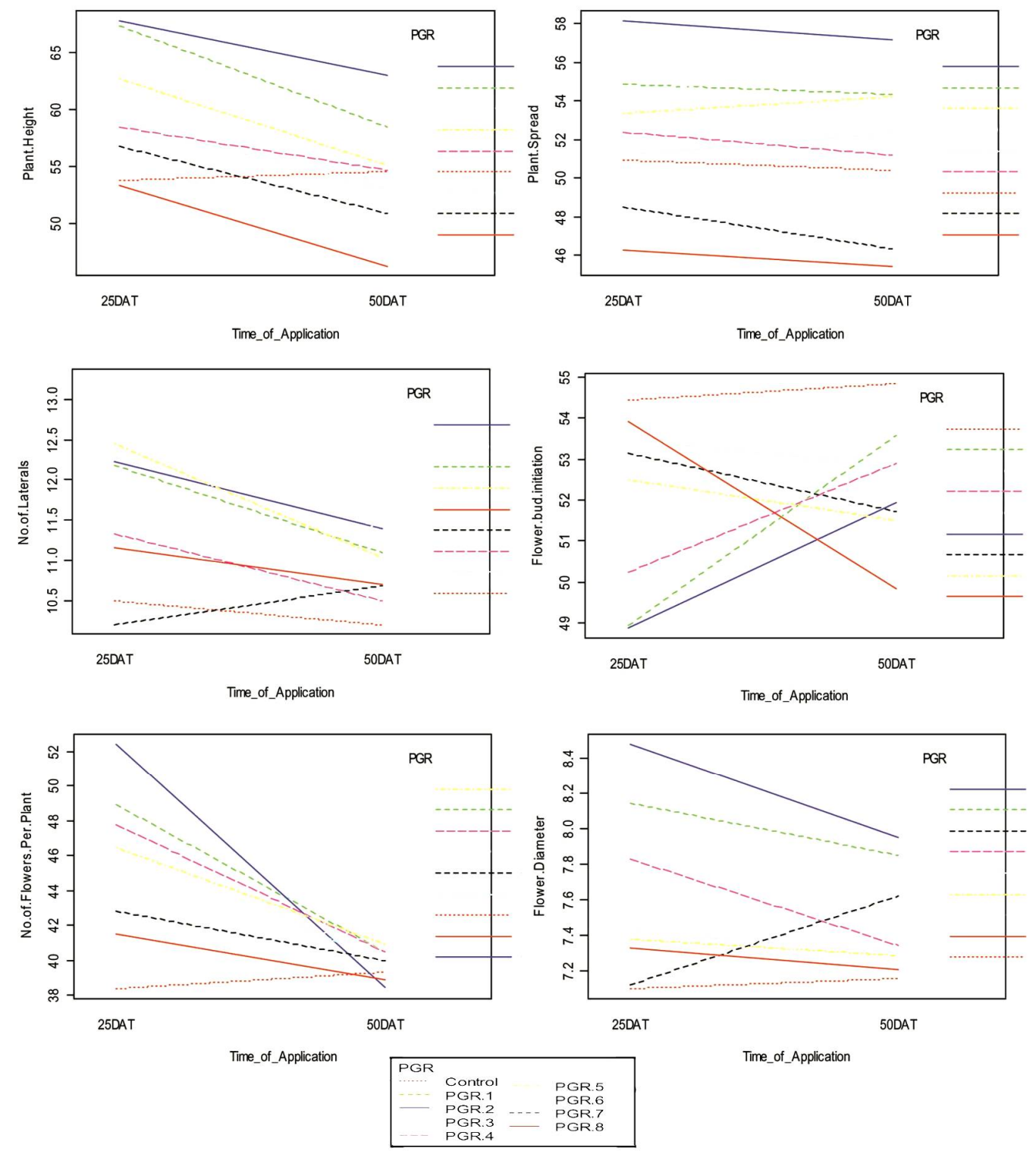

Fig. 1. Interaction plots of PGRs $\times$ time of application on plant height $(\mathrm{cm})$, plant spread $(\mathrm{cm})$, number of laterals, days taken to first flower bud initiation (days), flower diameter $(\mathrm{cm})$ in marigold cultivar Pusa Narangi Gainda. Control Distill water spray, PGR1 - 150 ppm GA 3 , PGR2 - 250 ppm GA 3 , PGR3 - 150 ppm salicylic acid, PGR4 - 200 ppm salicylic acid, PGR5 - 75 ppm benzyl adenine, PGR6 - 100 ppm benzyl adenine, PGR7 - 1000 ppm cycocel and PGR.8 - 1500 ppm cycocel. 

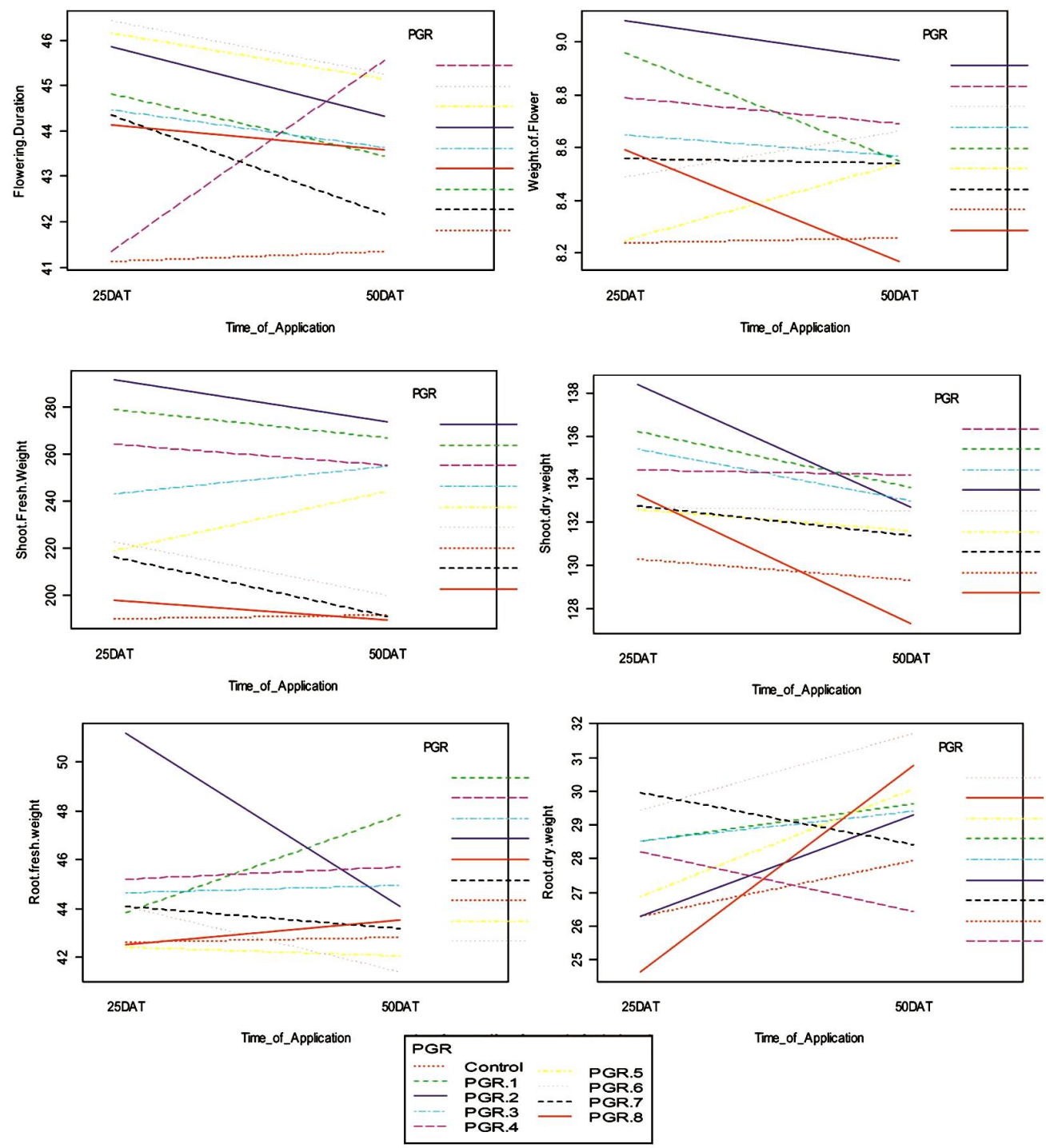

Fig. 2. Interaction plots of PGRs $\times$ time of application on flower duration (days), weight of flower(g), shoot fresh weight $(\mathrm{g})$, root fresh weight $(\mathrm{g})$, shoot dry weight $(\mathrm{g})$, root dry weight $(\mathrm{g})$ in marigold cultivar Pusa Narangi Gainda. Control - Distill water spray, PGR1 - 150 ppm GA 3 , PGR2 - 250 ppm GA 3 , PGR3 - 150 ppm salicylic acid, PGR4 200 ppm salicylic acid, PGR5 - 75 ppm benzyl adenine, PGR6 - 100 ppm benzyl adenine, PGR7 - 1000 ppm cycocel and PGR8 - 1500 ppm cycocel.

Improved flowering character when growth regulators were applied at 25 after transplanting might be due to higher photosynthetic ability (Khan et al. 2007) since the juvenile phase as well as better absorption of nutrient through improved growth leading to development of higher $\mathrm{C}: \mathrm{N}$ ratio resulted improved floriferousness. Kumar and Singh (2013) also reported improved floriferousness in calendula through application of $\mathrm{GA}_{3}$ at juvenile phase. 

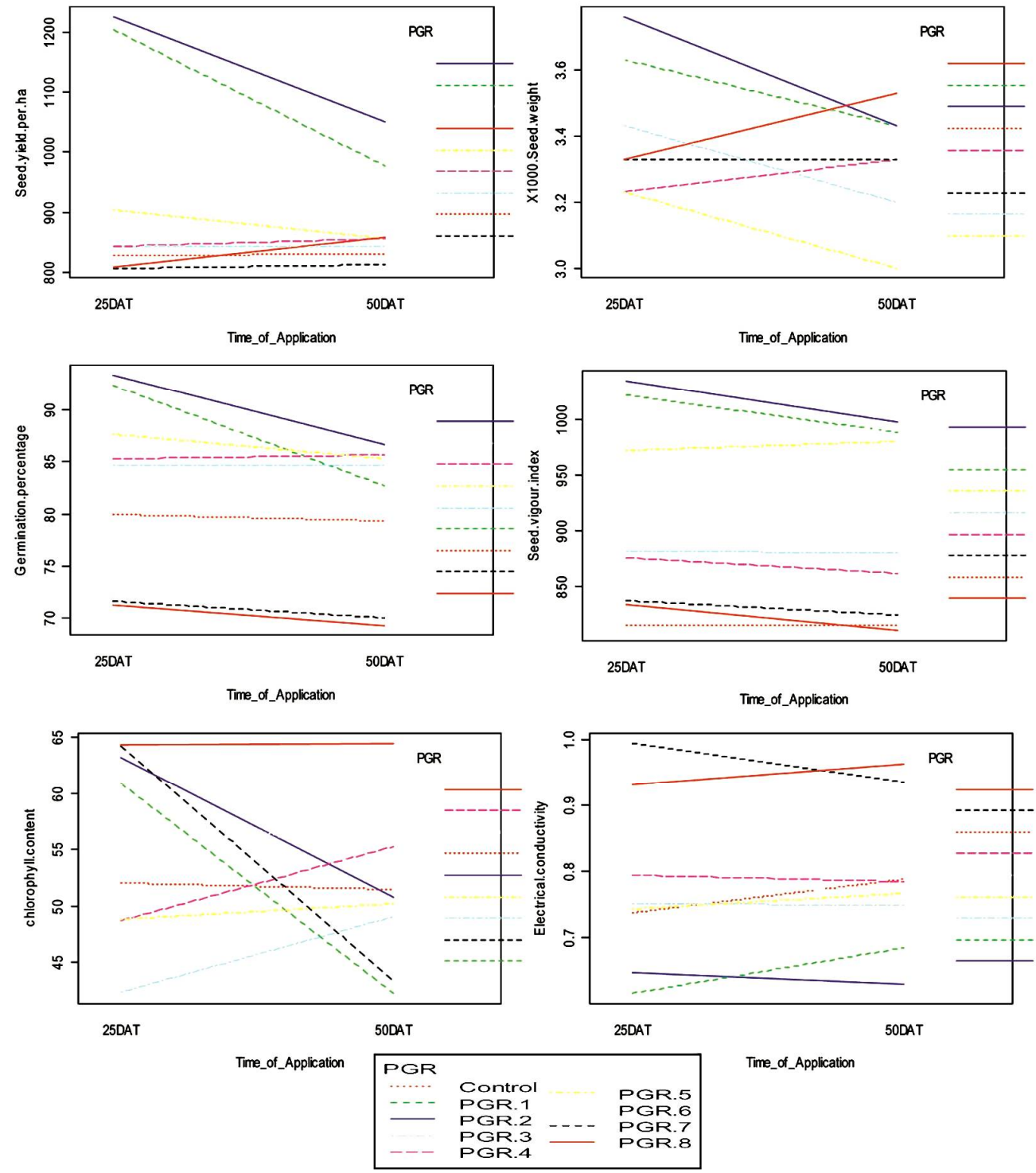

Fig. 3. Interaction plots of PGRs $\times$ time of application on root: shoot ratio, flower yield/plant (g), flower yield/plot $(\mathrm{kg})$, flower yield/hectare $(\mathrm{kg}), \quad(\mathrm{cm})$, seed yield/plant $(\mathrm{g})$, seed yield/plot $(\mathrm{kg})$, in marigold cultivar Pusa Narangi Gainda. Control - Distill water spray, PGR1 - 150 ppm GA 3 , PGR2 - 250 ppm GA 3 , PGR3 - 150 ppm salicylic acid, PGR4 200 ppm salicylic acid, PGR5 - 75 ppm benzyl adenine, PGR6 - 100 ppm benzyl adenine, PGR7 - 1000 ppm cycocel and PGR8 - 1500 ppm cycocel.

Foliar spray of $250 \mathrm{ppm}$ gibberellic acid given to the plants and the seeds harvested from such plants recorded significantly higher seed yield and superior seed quality parameters such as seed yield/plant (22.76 g), germination (90\%), vigour index (1016.50) and lowest electrical conductivity of seed leachate $(0.639 \mathrm{mu} \mathrm{mhos} / \mathrm{cm} / \mathrm{g})$. The increase in seed yield and quality parameters due to $\mathrm{GA}_{3}$ application might be because of the metabolic changes that influenced both quality and quantity to the desired level. $\mathrm{GA}_{3}$ also stimulated the synthesis of hydrolytic enzymes 
to act on starchy endosperm which in turn influenced the physiology of seed germination, vigour and establishment of seedlings. The improved seed yield and quality might also be due to better flower quality parameters with the same treatment.
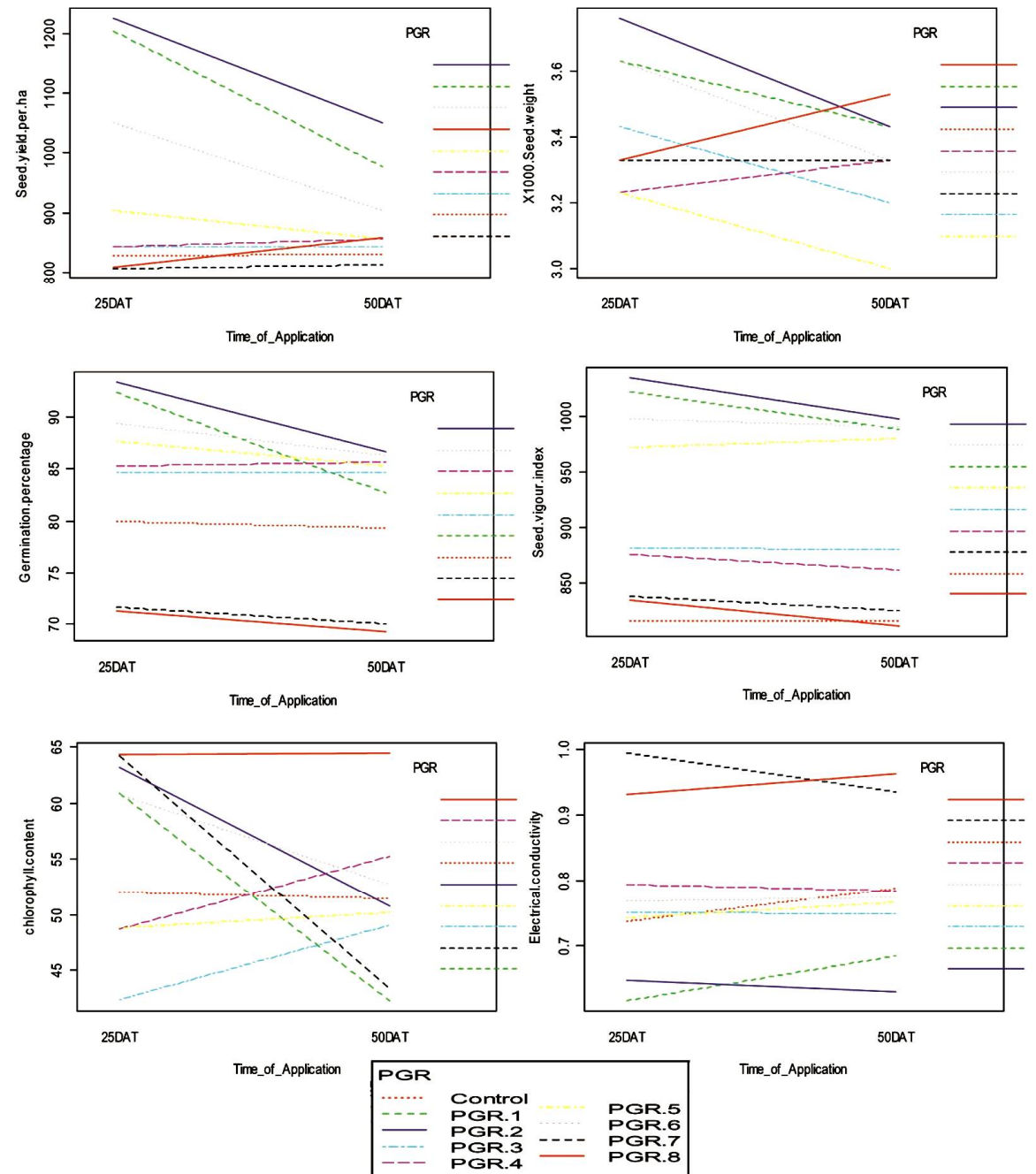

25DAT

Time_of_Application

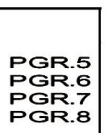

Fig. 4. Interaction plots of PGRs $\times$ time of application on root: seed yield/hectare $(\mathrm{kg}), 1000$-seed weight $(\mathrm{g})$, germination $(\%)$, seed vigour index, chlorophyll content $(\%)$, electrical conductivity $(\mathrm{mu} \mathrm{mhos} / \mathrm{cm} / \mathrm{g})$ in marigold cultivar Pusa Narangi Gainda. Control - Distill water spray, PGR1 - 150 ppm GA 3 , PGR2 - 250 ppm GA 3 , PGR3 - 150 ppm salicylic acid, PGR4 - 200 ppm salicylic acid, PGR5 - 75 ppm benzyl adenine, PGR6 - 100 ppm benzyl adenine, PGR7 - 1000 ppm cycocel and PGR8 - 1500 ppm cycocel.

Gupta and Gupta (2005) stated that gibberellins stimulate flowering and can cause fruit set by initiation of fruit growth, followed by pollination. Jong et al. (2009) reported that gibberellins play major role in the development of fruit and expression of genes in tomato. Increase in seed yield due to $\mathrm{GA}_{3}$ spray was also reported by Sunitha et al. (2007) in marigold, Sainath et al. (2014) in annual chrysanthemum and Kumar et al. (2015) in China aster. Increase in germination percentage due to growth regulators spray was also reported by Sunitha et al. (2007) in marigold. The 
minimum seed vigour index with the application of CCC is in line with the findings of Doddagoudar et al. (2004) in China aster.

Interaction effect showed that among the time of application, application at 25 days after transplanting recorded maximum seed yield/plant $(18.91 \mathrm{~g})$, germination percentage $(83.96 \%)$, seed vigour index (919.56) and lesser electrical conductivity of seed leachate $(0.776 \mathrm{mu}$ mhos $/ \mathrm{cm} / \mathrm{g}$ ). However, none of the plant growth regulator treatments and their application time could significantly affect the 1000-seed weight of marigold. Improved seed yield and quality parameters with application at 25 days after transplanting might be due to superior flower quality with the same treatment.

Interaction effect of plant growth regulators and time of application was found to be significant. Maximum plant height $(67.80 \mathrm{~cm})$, maximum plant spread $(58.15 \mathrm{~cm})$, minimum number of days taken to flower bud initiation (48.87 days), highest number of flowers per plant (52.43), maximum flower diameter $(8.48 \mathrm{~cm})$, maximum flowering duration (46.42 days), maximum weight of flower $(9.08 \mathrm{~g})$, maximum shoot fresh weight $(291.33 \mathrm{~g})$, maximum root fresh weight $(51.20 \mathrm{~g})$, highest root : shoot ratio on fresh weight basis $(0.291)$, highest flower yield/plant $(475.81 \mathrm{~g})$, maximum flower yield/plot $(7.61 \mathrm{~kg})$, maximum flower yield/ha $(23790.50$ $\mathrm{kg}$ ), maximum seed yield/plant (24.51 g), maximum seed yield/plot (392.16 g), maximum seed yield/ha $(1225.50 \mathrm{~kg})$, highest germination percentage $(93.33 \%)$, highest seed vigour index (1035.00), maximum chlorophyll content $(64.51 \%)$ were recorded with the application of 250 ppm Gibberellic acid at 25 DAT.

Maximum number of laterals (12.30) was recorded by foliar application of $100 \mathrm{ppm}$ benzyl adenine at 25 days after transplanting whereas minimum number of laterals (10.20) was recorded in control. Interaction effect of plant growth regulators and time of application shows maximum electrical conductivity of seed leachate $(0.994 \mathrm{mu} \mathrm{mhos} / \mathrm{cm} / \mathrm{g})$ with foliar application of $1000 \mathrm{ppm}$ Cycocel at 25 days after transplanting. However, minimum electrical conductivity $(0.616 \mathrm{mu}$ mhos $/ \mathrm{cm} / \mathrm{g}$ ) was recorded by $150 \mathrm{ppm}$ gibberellic acid at 25 days after transplanting. However, the interaction effect of plant growth regulators and time of application for shoot dry weigh, root dry weight and 1000-seed weight was found to be non-significant.

From the present study it may be concluded that among the foliar application of PGRs, application of $\mathrm{GA}_{3} @ 250 \mathrm{ppm}$ proved to be superior to other treatments in recording maximum values for parameters of economic importance. Whereas, among the times of application, foliar spray at 25 days after transplanting proved to be superior. The interaction effects of PGRs and times of application revealed that application of $\mathrm{GA}_{3} @ 250 \mathrm{ppm}$ at 25 days after transplanting for maximum increase in flower and seed yield parameters and in turn maximum returns.

\section{References}

Abel S and Theologis A 1996. Odyssey of auxin. In: Estelle M, Weijers D, Ljung K. and Leyser O. (Eds.) Perspective in Biology. Cold Spring Harbor Press, Leibniz-Institut Fuer, Germany, pp. 1-13.

Dalal SR, Karale GD and Momin KC 2009. Effect of growth regulators on growth, yield and quality of chrysanthemum under net house conditions. Asian J. Horticulture 4: 161-163.

Demura T and Ye ZH 2010. Regulation of plant biomass production. Current Opinion in Plant Biology 13(3): 298-303.

Devadanam A, Sable PB, Shinde BN and Haldewad AM 2007. Effect of foliar spray of plant growth regulators on growth and yield of tuberose (Polianthes tuberosa L.). J. Maharashtra Agricultural University 32(2): 282-283.

Doddagoudar SR, Vyakaranahal BS and Shekhargouda M 2004. Effect of mother plant nutrition and chemical spray on seed germination and seedling vigour index of China aster cv. Kamini. Karnataka J. Agricultural Science 17: 701-704. 
Gomez KA and Gomez AA 1985. Statistical Procedure for Agricultural Research. 2nd Edition. Awiley International Publication, Singapore. pp. 20-25.

Gupta NK and Gupta S 2005. Growth regulators. In: Gupta, N.K. and Gupta, S. (Eds.) Plant physiology. Oxford and IBH Publishing, New Delhi, pp. 286-349.

Jong MD, Mariani C and Vriezen WH 2009. The role of auxin and gibberellin in tomato fruit set. J. Experimental Botany 60: 1523-1532.

Khan NA, Singh S, Nazar R and Lone PM 2007. The source-sink relationship in mustard. The Asian and Australasian J. Plant Sci. and Biotechnol. 1:10-18.

Kumar J, Singh AK and Pal K 2009. Effect of $\mathrm{GA}_{3}$ and urea on growth and flowering in tuberose (Polianthes tuberosa L.) cv. Pearl Double. Annals of Horticulture 2(2): 201-203.

Kumar KP, Padmalatha T, Pratap M and Reddy SN 2015. Effect of plant bio-regulators on growth, flowering and seed yield in China aster (Callistephus chinensis L. Nees) cv. Kamini Indian J. Agricultural Research 49(4): 348-352.

Kumar M, Singh AK and Kumar A 2014. Effect of plant growth regulators on flowering and yield attributes of African marigold (Tagetes erecta L.) cv Pusa Narangi Gainda. Plant Archives. 14(1): 363-365.

Kumar R and Singh K 2013. Effect of growth regulator and shoot tip pinching on carnation. J. Ornamental Horticulture 6(2): 134-136.

Lockhart JA 1960. Inter-cellular mechanism growth inhibitor of radian energy. Plant Physiol. 35: 129- 135.

Meher SP, Doijode DJ, Turkhede AB, Darange PU, Ghatol PU and Dhawad CS 1999. Effect of planting time and growth regulator treatments on flowering and yield of chrysanthemum (Chrysanthemum morifolium). Crop Res. 18(3): 293-295.

Morris DA 1996. Hormonal regulation of source-sink relationships: an overview of potential control mechanisms. In: Photo assimilate distribution in plants and crops. Source-sink relationships. Zamski, E. \& Schaffer, AA (Eds.). Marcel Dekker, New York, pp. 441- 466.

Mutui TM, Emongor VN and Hutchinson MJ 2004. Effect of benzyl adenine on the vase life and keeping quality of Alstoemeria cut flowers. Food and Agricultural Organization of the United Nations 5(1): 91105.

Sainath, Uppar DS, Patil VS, Deshpande VK and Hunje R 2014. Effect of different growth regulators on seed yield and quality attributes in annual chrysanthemum (Chrysanthemum coronarium L.). Karnataka J. Agricultural Science 27(2): 131-134.

Salisbury FB and Ross CW 1999. Plant physiology. Wadsworth Publishing. 593 p.

Singh J, Rajbeer and Kumar J 2009. Effect of $\mathrm{GA}_{3}, \mathrm{CCC}$ and inorganic fertilizers on growth and flowering in chrysanthemum (Dendranthema grandiflora Ramat.) cv. Birbal Sahni. Annals of Horticulture 2(2): 232233.

Sujatha K, Gowda JVN and Khan MM 2002. Effects of different fertigation levels on gerbera under low cost greenhouse. J. of Ornamental Horticulture New Series 5(1): 54-59.

Sunitha HM, Hunje R, Vyakaranahal BS and Bablad HB 2007. Effect of pinching and growth regulators on plant growth, flowering and seed yield in African marigold (Tagetes erecta L.). J. Ornamental Horticulture 10(3):197-198.

Syiemlieh S, Saravanan MB and Prasad VM 2016. Effect of plant growth regulator on plant growth and flower yield of petunia (Petunia $x$ hybrida) cv. Purple Prince. International J. Research in Applied Natural and Social Science 4(8): 107-112.

Tripathi AN, Tripathi SN, Shakula RK and Pandey G 2013. Effect of GA, NAA and CCC on growth and flowering of French marigold (Tagetes patula). J. Applied Horticulture 5(2): 112-113.

Tyagi AK and Kumar V 2006. Effect of Gibberellic acid and vermin compost on vegetative growth and flowering in African marigold (Tagetes erecta Linn.). J. Ornamental Horticulture 9: 150-151.

Verma LR and Arha. 2004. Studies on regulation of flowering in African marigold (Tagetes erecta L.) by the application of $\mathrm{GA}_{3}$, ethrel and MH. J. Ornamental Horticulture 7(3-4): 168-170. 